\title{
Laboratory Prototype of Bioreactor for Oxidation of Toxic D-Lactate Using Yeast Cells Overproducing D-Lactate Cytochrome $c$ Oxidoreductase
}

\author{
Maria Karkovska, Oleh Smutok, and Mykhailo Gonchar \\ Department of Analytical Biotechnology, Institute of Cell Biology, Drahomanov Street 14/16, Lviv 79005, Ukraine \\ Correspondence should be addressed to Oleh Smutok; smutok@cellbiol.lviv.ua
}

Received 25 April 2016; Accepted 7 June 2016

Academic Editor: Subash C. B. Gopinath

Copyright (C) 2016 Maria Karkovska et al. This is an open access article distributed under the Creative Commons Attribution License, which permits unrestricted use, distribution, and reproduction in any medium, provided the original work is properly cited.

D-lactate is a natural component of many fermented foods like yogurts, sour milk, cheeses, and pickles vegetable products. D-lactate in high concentrations is toxic for children and people with short bowel syndrome and provokes encephalopathy. These facts convincingly demonstrate a need for effective tools for the D-lactate removal from some food products. The main idea of investigation is focused on application of recombinant thermotolerant methylotrophic yeast Hansenula polymorpha "tr6," overproducing D-lactate: cytochrome $c$ oxidoreductase (EC 1.1.2.4, D-lactate cytochrome $c$ oxidoreductase, D-lactate dehydrogenase (cytochrome), DLDH). In addition to 6-fold overexpression of DLDH under a strong constitutive promoter

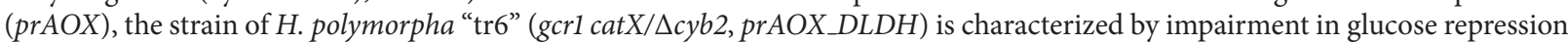
of AOX promoter, devoid of catalase and L-lactate-cytochrome $c$ oxidoreductase activities. Overexpression of DLDH coupling with the deletion of L-lactate-cytochrome $c$ oxidoreductase activity opens possibility for usage of the strain as a base for construction of bioreactor for removing D-lactate from fermented products due to oxidation to nontoxic pyruvate. A laboratory prototype of column-type bioreactor for removing a toxic D-lactate from model solution based on permeabilized cells of the H. polymorpha "tr6" and alginate gel was constructed and efficiency of this process was tested.

\section{Introduction}

D-lactate is a natural component of many fermented foods like yogurts [1,2], sour milk [3], cheeses [4], and pickles vegetable products [5].

D-lactate can be metabolized slowly in the human body in comparison with L-lactate isomer and can cause metabolic disorders if ingested in excess. Therefore, the World Health Organization (WHO) recommends a limited daily consumption of D-lactate up to $100 \mathrm{mg} \cdot \mathrm{kg}^{-1}$ bodyweight. Moreover, some countries, for example, Germany, have decided to minimize the D-lactate content of fermented dairy products [6]. The high concentration of D-lactate is toxic for children [7] and people with short bowel syndrome [8-10]. Also D-lactate toxicity depends on physiological state of renal excretion. Hingorani et al. demonstrated that, in healthy men continuously infused with a D-lactate solution, excretion rates ranged between 61 and 100\% [11]. In 1993, there was reported a case of chronic D-lactate encephalopathy occurring in a patient with short bowel syndrome and end-stage renal disease [12].

Originally, it was believed that, due to the lack of enzyme D-lactate dehydrogenase in humans, they are not able to metabolize D-lactate to pyruvate. However, in the past two decades there is an abundance of literature suggesting the presence of a D-lactate metabolizing enzyme D-2-hydroxy acid dehydrogenase (D-2-HDH) that is mainly found in the liver and kidney $[10,13]$. This enzyme is inhibited by low-pH states, which assumes importance in the relative overproduction of D-lactate in certain clinical situations. Dlactic acidosis or D-lactate encephalopathy is a rare condition that occurs primarily in individuals who have a history of short bowel syndrome (SBS).

The predominant organ system affected by D-lactic acidosis is the central nervous system (CNS). Presenting symptoms 
may include slurred speech, ataxia, altered mental status, psychosis, or even coma $[8,9,14,15]$.

The aim of the current work is construction of an effective laboratory prototype of bioreactor for removing Dlactate from fermented products based on the use of yeast cells overproducing D-lactate oxidoreductase. The D-lactate oxidoreductase (cytochrome $c$-dependent dehydrogenase, DLDH, EC1.1.2.4) is a FAD- and $\mathrm{Zn}^{2+}$-containing membraneassociated protein found in yeast and bacteria. The enzyme catalyzes D-lactate oxidation to pyruvate coupled with ferricytochrome $c$ reduction to ferrocytochrome $c$. It is characterized as a mitochondrial protein with a molecular weight of $63 \mathrm{kDa}$ for $\mathrm{DLDH}$ from Kluyveromyces lactis and $64 \mathrm{kDa}$ for DLDH from Saccharomyces cerevisiae, respectively [16, 17]. DLDH is highly selective to D-lactate; however, D,L- $\alpha$ hydroxybutyric acid can be used as an alternative electron donor. The enzyme is not selective with respect to electron acceptors and can reduce, in addition to its native acceptor (cytochrome $c$ ), different low molecular artificial redox mediators (ferricyanide, dichlorphenol indophenols, etc.).

We propose using recombinant DLDH-overproducing strain $H$. polymorpha "tr6" (gcrl catX/Dcyb2, prAOX DLDH) as a base for construction of laboratory prototype of bioreactor for removing a toxic D-lactate from fermented products. The column-type bioreactor includes alginate gel formations with incorporated permeabilized yeast cells.

\section{Material and Methods}

2.1. Materials. Sodium D-lactate, sodium alginate, and phenylmethylsulfonyl fluoride (PMSF) were purchased from Sigma-Aldrich Corp. (Deisenhofen, Germany) and cetyltrimethylammonium bromide (CTAB) was purchased from Chemapol Sp. (Bratislava, Slovakia). D(+)-glucose monohydrate was purchased from J. T. Baker (Deventer, Netherlands). $\left(\mathrm{NH}_{4}\right)_{2} \mathrm{SO}_{4}, \mathrm{Na}_{2} \mathrm{HPO}_{4}, \mathrm{KH}_{2} \mathrm{PO}_{4}, \mathrm{MgSO}_{4}$, and $\mathrm{CaCl}_{2}$ were obtained from Merck (Darmstadt, Germany). All chemicals and reagents were of analytical grade and all solutions were prepared using deionized water. D-lactate standard solution and appropriate dilutions were prepared in $100 \mathrm{mM}$ phosphate buffer (PB), pH 7.8.

2.2. Cultivation and Permeabilization of Yeast Cells. Recombinant DLDH-overproducing strain H. polymorpha "tr6" ( $\left.g c r 1 c a t X / \Delta c y b 2, \operatorname{pr} A O X \_D L D H\right)$ is characterized by 6-fold overexpression of DLDH, impaired in glucose repression, devoid of catalase and specific L-lactate-cytochrome $c$ oxidoreductase activities, which was constructed by us earlier [18].

Cultivation of the $H$. polymorpha "tr6" was performed in flasks on a shaker $(200 \mathrm{rpm})$ at $28^{\circ} \mathrm{C}$ until the middle of the stationary growth phase $(\sim 52 \mathrm{~h})$ in a medium containing $\left(\mathrm{g} \cdot \mathrm{L}^{-1}\right):\left(\mathrm{NH}_{4}\right)_{2} \mathrm{SO}_{4}, 3.5 ; \mathrm{KH}_{2} \mathrm{PO}_{4}, 1.0$; and $\mathrm{MgSO}_{4} \times 7 \mathrm{H}_{2} \mathrm{O}$, 0.5 , supplemented with $0.75 \%$ yeast extract. A mixture of glucose $\left(10 \mathrm{~g} \cdot \mathrm{L}^{-1}\right)$ and D-lactate $\left(2 \mathrm{~g} \cdot \mathrm{L}^{-1}\right)$ was used as a carbon and energy source and $\left(1 \mathrm{~g} \cdot \mathrm{L}^{-1}\right)$ methanol as an inductor for $A O X$ promoter. After washing, the cells were suspended in $50 \mathrm{mM}$ PB, pH 7.8, containing $1 \mathrm{mM}$ PMSF.
Before experiments, the freshly prepared yeast cells were resuspended to $30 \mathrm{mg} \cdot \mathrm{mL}^{-1}$ in $50 \mathrm{mM} \mathrm{PB}, \mathrm{pH} 7.8$, and stored in refrigerator.

The procedure of the cells permeabilization was as follows: the same volume of permeabilizing reagent $(0.85 \mathrm{mM}$ CTAB) was added to the cell suspension $\left(30 \mathrm{mg} \cdot \mathrm{mL}^{-1}\right.$ in $50 \mathrm{mM} \mathrm{PB}, \mathrm{pH} 7.8$ ). The resulting solution was treated at $30^{\circ} \mathrm{C}$ in a water bath for $15 \mathrm{~min}$ under mixing every 3-4 min. The permeabilized cells were washed by centrifugation $(6000 \times \mathrm{g}$, $5 \mathrm{~min}$ ) in $10 \mathrm{mM} \mathrm{PB}, \mathrm{pH}$ 7.8. The precipitated permeabilized cells were resuspended to $30 \mathrm{mg} \cdot \mathrm{mL}^{-1}$ in the same buffer solution and stored at $+4^{\circ} \mathrm{C}$. A half-life of the permeabilized yeast cells was about three weeks of storage at such conditions.

2.3. Assay of DLDH Activity in Permeabilized Cells. One unit $(1 \mathrm{U})$ of the $D L D H$ activity is defined as that amount of the enzyme which forms $1 \mu \mathrm{mol}$ hexacyanoferrate(II) per minute under standard conditions of the assay $\left(20^{\circ} \mathrm{C}, 30 \mathrm{mM} \mathrm{PB}\right.$, and $\mathrm{pH}$ 7.8). Activity was estimated by spectrophotometric monitoring of hexacyanoferrate(III) reduction at $\lambda=420 \mathrm{~nm}$ [19]. During this process, optical density of the analyzed solution becomes lower. Assay mixture consisted of $30 \mathrm{mM} \mathrm{PB}, \mathrm{pH} 7.8$; $16 \mathrm{mM}$ sodium D-lactate; $0.83 \mathrm{mM} \mathrm{K}_{3} \mathrm{Fe}(\mathrm{CN})_{6}$; and $20 \mu \mathrm{L}$ of diluted permeabilized cell suspension $\left(30 \mathrm{mg} \cdot \mathrm{mL}^{-1}\right)$.

The specific activity of DLDH was calculated by the following formula:

$$
\mathrm{SA}=\frac{\Delta E / \mathrm{min} \cdot V \cdot n}{E \mathrm{mM} \cdot C \text { cells } \cdot V \text { cells }},
$$

where $\Delta E / \mathrm{min}$ is change of optical density at $\lambda=420 \mathrm{~nm}$ per $\min ; V$ is total volume of the assay solution, $\mathrm{mL} ; n$ is dilution of the enzyme before assay; EmM is millimolar extinction of hexacyanoferrate(III), $1.04 \mathrm{mM}^{-1} \cdot \mathrm{cm}^{-1} ; V$ cells is volume of the added permeabilized cell suspension, $\mathrm{mL}$; and Ccells is permeabilized cell concentration, $\mathrm{mg} \cdot \mathrm{mL}^{-1}$.

Specific DLDH activity in the cells was calculated by the following formula, considering difference between specific DLDH activity (+D-lactate) and nonspecific ferrireductase activity (without D-lactate): $A=A_{+\mathrm{D} \text {-lact }}-A_{-\mathrm{D} \text {-lact }}$.

\section{Results and Discussion}

The possibility of usage of DLDH-producer as a perspective tool for D-lactate removing from fermented products was investigated. For analysis of D-lactate utilization ability of the recombinant thermotolerant methylotrophic yeast Hansenula polymorpha "tr6" (gcrl catX/ $\triangle c y b 2$, prAOX_DLDH) constructed by us earlier, overproducing DLDH was chosen. The $H$. polymorpha DLDH-producer was constructed in two steps. First, the gene CYB2 was deleted on the background of the C-105 ( $g c r l, c a t X)$ strain of $H$. polymorpha impaired in glucose repression and devoid of catalase activity to avoid specific L-lactate-cytochrome $c$ oxidoreductase activity. Second, the homologous gene DLD1 coding for DLDH was overexpressed under the control of the strong $H$. polymorpha alcohol oxidase promoter in the frame of a plasmid for multicopy integration in the $\Delta c y b 2$ strain. The selected recombinant strain possesses 6-fold increased DLDH activity as 
TABLE 1: The residual D-lactate concentration by Buchner method in the samples selected using two types of the H. polymorpha "tr6" cells analyzed.

\begin{tabular}{lcc}
\hline $\begin{array}{l}\text { Time of } \\
\text { incubation, min }\end{array}$ & $\begin{array}{c}\text { D-lactate, } \mathrm{mM} \\
\text { (permeabilized cells) }\end{array}$ & $\begin{array}{c}\text { D-lactate, } \mathrm{mM} \\
\text { (intact cells) }\end{array}$ \\
\hline 0 & $20.0 \pm 0.00$ & $20.0 \pm 0.00$ \\
10 & $19.3 \pm 0.15$ & $19.87 \pm 0.14$ \\
20 & $15.5 \pm 0.2$ & $18.5 \pm 0.18$ \\
30 & $11.9 \pm 0.23$ & $15.51 \pm 0.25$ \\
40 & $11.98 \pm 0.28$ & $14.48 \pm 0.29$ \\
50 & $12.5 \pm 0.30$ & $14.5 \pm 0.22$ \\
\hline
\end{tabular}

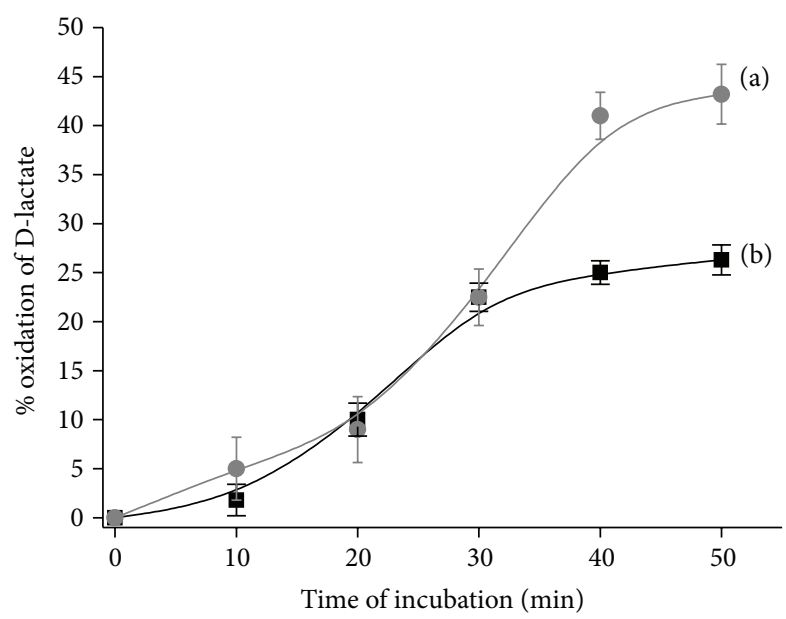

FIgURE 1: The profile of D-lactate oxidation using recombinant H. polymorpha "tr6" cells: (a) permeabilized and (b) living cells. Conditions: $10 \mathrm{mM} \mathrm{PB}, \mathrm{pH} 7.8,30^{\circ} \mathrm{C}$, and shaking $(200 \mathrm{rpm})$ at $30^{\circ} \mathrm{C}$; the initial concentration of D-lactate was $20 \mathrm{mM}$.

compared to the initial strain [18]. Two types of yeast cells (intact and permeabilized) were tested. The experiment was carried out as follows: to $50 \mathrm{~mL}$ of $10 \mathrm{mM} \mathrm{PB}, \mathrm{pH} 7.8$, we added D-lactate (with a final concentration $20 \mathrm{mM}$ ) and $0.1 \mathrm{~g}$ of the intact yeast cells with specific enzymatic activity $12.6 \mathrm{U} \cdot \mathrm{mg}^{-1}$. An incubation of the same amount of permeabilized cells of the H. polymorpha "tr6" (with DLDH activity of $11.7 \mathrm{U} \cdot \mathrm{mg}^{-1}$ ) in the same mixture was performed in parallel. The amount of the added yeast cells of two types was calculated related to the specific DLDH activity. The obtained cell mixture was incubated about one hour at a shaker $\left(200 \mathrm{rev} \cdot \mathrm{min}^{-1}\right)$ at $30^{\circ} \mathrm{C}$. Every 10 minutes, $2 \mathrm{~mL}$ of the mixture was taken, centrifugated $(6000 \times \mathrm{g}, r=8 \mathrm{~cm}, 2 \mathrm{~min})$ and the eluates were frozen at $-20^{\circ} \mathrm{C}$. The residual D-lactate in the frozen samples was analyzed chemically by Buchner method [20] after completing the experiment (Table 1).

The profile of D-lactate utilization using recombinant $H$. polymorpha "tr6" cells is represented in Figure 1.

As shown in Figure 1, effectiveness of D-lactate oxidation (during 40-minute incubation) was calculated as $28 \%$ for intact yeast cells (activity of DLDH, $12.6 \mathrm{U} \cdot \mathrm{mg}^{-1}$ ), whereas for the permeabilized cells (with activity of DLDH, $11.2 \mathrm{U} \cdot \mathrm{mg}^{-1}$ )

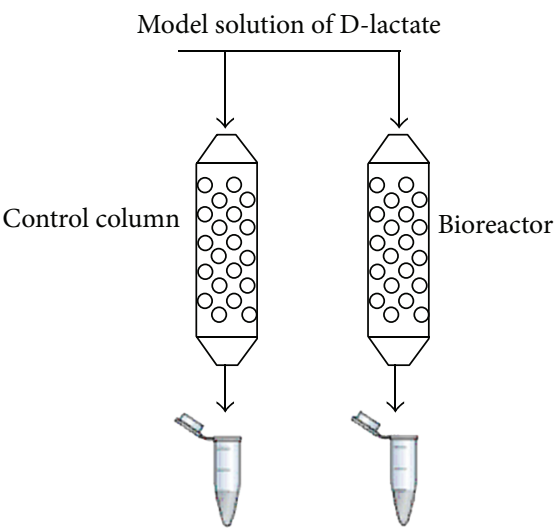

FIGURE 2: Principal scheme of bioreactor prototype based on permeabilized recombinant yeast cells for removing D-lactate from aqueous solution. The control column contains alginate gel without the cells.

it was about $41 \%$. The average productivity of the process (for $30 \mathrm{~min}$ incubation) was about $9.0 \mathrm{mmol} \cdot \mathrm{L}^{-1} \cdot \mathrm{h}^{-1}$. It was shown that the permeabilized yeast cells are 1.5 -fold more effective agent for removal of D-lactate in comparison with intact living cells. Probably this effect could be explained by higher permeability of permeabilized cells to substrate. Thus, for construction of cell-based bioreactor for D-lactate oxidation, permeabilized yeast cells of $H$. polymorpha "tr6" are more effective.

A column-type bioreactor based on permeabilized yeast cells of $H$. polymorpha "tr6" incorporated in alginate gel was constructed. The immobilization of the yeast cells in calcium alginate gel was performed as follows: $2 \mathrm{~mL}$ suspension of permeabilized $H$. polymorpha "tr6" cells $\left(60 \mathrm{mg} \cdot \mathrm{mL}^{-1}\right)$ was mixed with $2 \mathrm{~mL}$ of $4 \%(\mathrm{w} / \mathrm{v})$ sodium alginate. The obtained mixture was put to medical syringe and dropped through a needle into solution of $\mathrm{CaCl}_{2}\left(40 \mathrm{mg} \cdot \mathrm{mL}^{-1}\right)$. The formed alginate beads (diameter around $3 \mathrm{~mm}$ ) with incorporated permeabilized yeast cells were placed to columns $1 \times 10 \mathrm{~cm}$ (4 mL gel). As a control, "bare" alginate gel without the cells (Figure 2) was used.

The packed columns were washed by $3 \mathrm{~mL}$ of $\mathrm{PB}, \mathrm{pH}$ 7.8, prior to the experiment beginning. As a model solution, $20 \mathrm{mM}$ of D-lactate in $50 \mathrm{mM} \mathrm{PB}, \mathrm{pH} 7.8$, containing $1 \mathrm{mM}$ $\mathrm{CaCl}_{2}$ was used.

For optimisation of flow rate for high efficiency of D-lactate oxidation, the model solution was simultaneously passed through both columns with different speed: $50 \mathrm{~mL} \cdot \mathrm{min}^{-1}$ and $10 \mathrm{~mL} \cdot \mathrm{min}^{-1}$. Due to difference in flow rate through the alginate gel the first column with a speed $50 \mathrm{~mL} \cdot \mathrm{min}^{-1}$ was marked as a "bioreactor 1" and the other one (flow rate $10 \mathrm{~mL} \cdot \mathrm{min}^{-1}$ ) was marked as "bioreactor 2," respectively. Every $15 \mathrm{~min}$, a small amount $(0.2 \mathrm{~mL})$ of mixture flowing through the columns was collected and frozen at $-20^{\circ} \mathrm{C}$. After finishing the experiment, a residual D-lactate in the frozen samples was analyzed by Buhner chemical method of lactate assay (Figure 3). 


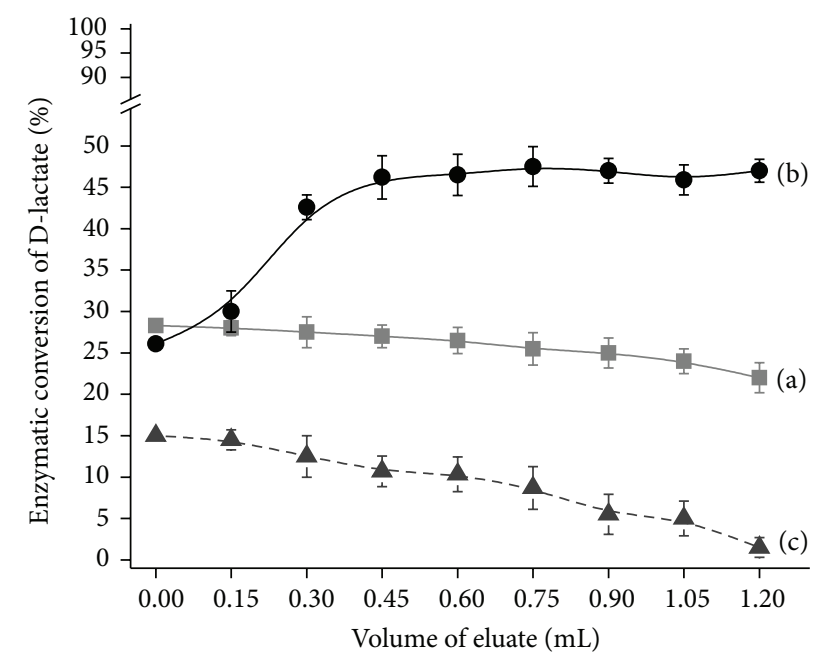

Figure 3: Optimisation of flow rate for enzymatic D-lactate conversion using a column bioreactor, (a) flow rate $50 \mathrm{~mL} \cdot \mathrm{min}^{-1}$ and (b) flow rate $10 \mathrm{~mL} \cdot \mathrm{min}^{-1}$, and (c) control column, flow rate $10 \mathrm{~mL} \cdot \mathrm{min}^{-1}$. Conditions: enzymatic activity of DLDH in permeabilized cells was $80 \mathrm{U} \cdot \mathrm{mL}^{-1}$, and the initial D-lactate concentration was $20 \mathrm{mM}$ in the presence of $1 \mathrm{mM} \mathrm{CaCl}_{2}$.

As was shown in Figure 3, both columns are able to remove D-lactate from the model solution. However, the effectiveness of this process was significantly different and depended on the flow rate through the columns. Thus, in the case of "bioreactor 1" enzymatic conversion of $2 \mathrm{~mL} 20 \mathrm{mM}$ D-lactate was ranged between 15 and 28\%. "Bioreactor 2" showed a twofold higher efficiency of D-lactate oxidation at the same volume of model solution (45-53\%). The control alginate column was used to analyze the possibility of nonenzymatic conversion of D-lactate. As was clearly shown in Figure 3, nonenzymatic conversion of D-lactate in control reactor did not occur and the observed decrease in D-lactate concentration (about 14\%) was caused by a partial dilution of sample as a result of washing the column by buffer.

The obtained results clearly confirmed the possibility of using permeabilized cells, immobilized in alginate gels, of recombinant DLDH-overproducing strain of $H$. polymorpha "tr6" as a catalyst for bioreactor able to remove D-lactate from fermented food products. It was shown that efficiency of enzymatic conversion of D-lactate for bioreactor prototype tightly depends on the flow rate through the column.

The usage of the developed cell-based prototype for removing toxic D-lactate from fermented products is in progress.

\section{Conclusions}

A laboratory prototype of column-type bioreactor for Dlactate removing from model solution based on permeabilized yeast cells of the $H$. polymorpha "tr6" and alginate gel has been constructed and efficiency of this process has been demonstrated. The optimal concentration of the permeabilized cells (with DLDH activity of $11.2 \mathrm{U} \cdot \mathrm{mg}^{-1}$ ) was estimated as $30 \mathrm{mg}$ per $1 \mathrm{~mL}$ of $4 \%$ alginate. It was shown that efficiency of enzymatic oxidation of D-lactate by the bioreactor prototype tightly depends on flow rate through the column. The laboratory cell-based bioreactor would be useful in food technology for removing toxic D-lactate.

\section{Competing Interests}

The authors declare that there is no conflict of interests regarding the publication of this paper.

\section{Acknowledgments}

This research was supported in part by NAS of Ukraine in the frame of the Scientific-Technical Program "Sensor systems for medical, ecological and industrial-technological needs: metrological assurance and research exploitation," as well as by NATO Project SfP 984173.

\section{References}

[1] M. de Vrese, B. Koppenhoefer, and C. A. Barth, "D-lactic acid metabolism after an oral load of dl-lactate," Clinical Nutrition, vol. 9, no. 1, pp. 23-28, 1990.

[2] C. S. K. Mishra and P. Champagne, Eds., Biotechnology Applications, I. K. International Publishing House, New Delhi, India, 2009.

[3] C. Scheele, The Collected Papers of Carl WilhelmScheele, G. Bell, London, UK, 1931.

[4] Megazyme, "D-lactate acid (D-lactate) and L-lactate acid (Llactate) assay procedures," 2007, https://secure.megazyme.com/ D-Lactic-Acid-Assay-Kit.

[5] D. L. Zhang, Z. W. Jiang, J. Jiang, B. Cao, and J. S. Li, "D-lactic acidosis secondary to short bowel syndrome," Postgraduate Medical Journal, vol. 79, no. 928, pp. 110-112, 2003.

[6] A. Zourari, J. P. Accolas, and M. J. Desmazeaud, "Metabolism and biochemical characteristics of yogurt bacteria. A review," Le Lait, vol. 72, no. 1, pp. 1-34, 1992.

[7] L. Stolberg, R. Rolfe, N. Gitlin et al., "D-Lactic acidosis due to abnormal gut flora. Diagnosis and treatment of two cases," The New England Journal of Medicine, vol. 306, no. 22, pp. 1344$1348,1982$.

[8] M. Hudson, R. Pocknee, and N. A. G. Mowat, "D-Lactic acidosis in short bowel syndrome-an examination of possible mechanisms," Quarterly Journal of Medicine, vol. 74, no. 274, pp. 157-163, 1990.

[9] A. S. Day and G. D. Abbott, "D-lactic acidosis in short bowel syndrome," The New Zealand Medical Journal, vol. 112, no. 1092, pp. 277-278, 1999.

[10] N. Gurukripa Kowlgi and L. Chhabra, "D-lactic acidosis: an underrecognized complication of short bowel syndrome," Gastroenterology Research and Practice, vol. 2015, Article ID 476215, 8 pages, 2015.

[11] A. D. Hingorani, I. C. Macdougall, M. Browne, R. W. H. Walker, and C. R. V. Tomson, "Successful treatment of acute Dlactate encephalopathy by haemodialysis," Nephrology Dialysis Transplantation, vol. 8, no. 11, pp. 1283-1285, 1993.

[12] J. R. Thurn, G. L. Pierpont, C. W. Ludvigsen, and J. H. Eckfeldt, "D-lactate encephalopathy," The American Journal of Medicine, vol. 79, no. 6, pp. 717-721, 1985. 
[13] H. Hove and P. B. Mortensen, "Colonic lactate metabolism and D-lactic acidosis," Digestive Diseases and Sciences, vol. 40, no. 2, pp. 320-330, 1995.

[14] B. E. Coronado, S. M. Opal, and D. C. Yoburn, "Antibioticinduced D-lactic acidosis," Annals of Internal Medicine, vol. 122, no. 11, pp. 839-842, 1995.

[15] S. C. Kadakia, "D-lactic acidosis in a patient with jejunoileal bypass," Journal of Clinical Gastroenterology, vol. 20, no. 2, pp. 154-156, 1995.

[16] T. Lodi and I. Ferrero, "Isolation of the DLD gene of Saccharomyces cerevisiae encoding the mitochondrial enzyme Dlactate ferricytochrome c oxidoreductase," Molecular and General Genetics, vol. 238, no. 3, pp. 315-324, 1993.

[17] T. Lodi, D. O'Connor, P. Goffrini, and I. Ferrero, "Carbon catabolite repression in Kluyveromyces lactis: isolation and characterization of the KINLD gene encoding the mitochondrial enzyme D-lactate ferricytochrome c oxidoreductase," Molecular and General Genetics, vol. 244, no. 6, pp. 622-629, 1994.

[18] O. V. Smutok, K. V. Dmytruk, M. I. Karkovska, W. Schuhmann, M. V. Gonchar, and A. A. Sibirny, "D-lactate-selective amperometric biosensor based on the cell debris of the recombinant yeast Hansenula polymorpha," Talanta, vol. 125, pp. 227-232, 2014.

[19] C. A. Appleby and R. K. Morton, "Lactic dehydrogenase and cytochrome $b_{2}$ of baker's yeast; purification and crystallization," The Biochemical journal, vol. 71, no. 3, pp. 492-499, 1959.

[20] E. Buchner and K. Schottenhammer, "Die Einwirkung von Diazo-essigester auf Mesitylen," Berichte der Deutschen Chemischen Gesellschaft ( $A$ and B Series), vol. 53, no. 6, pp. 865-873, 1920. 

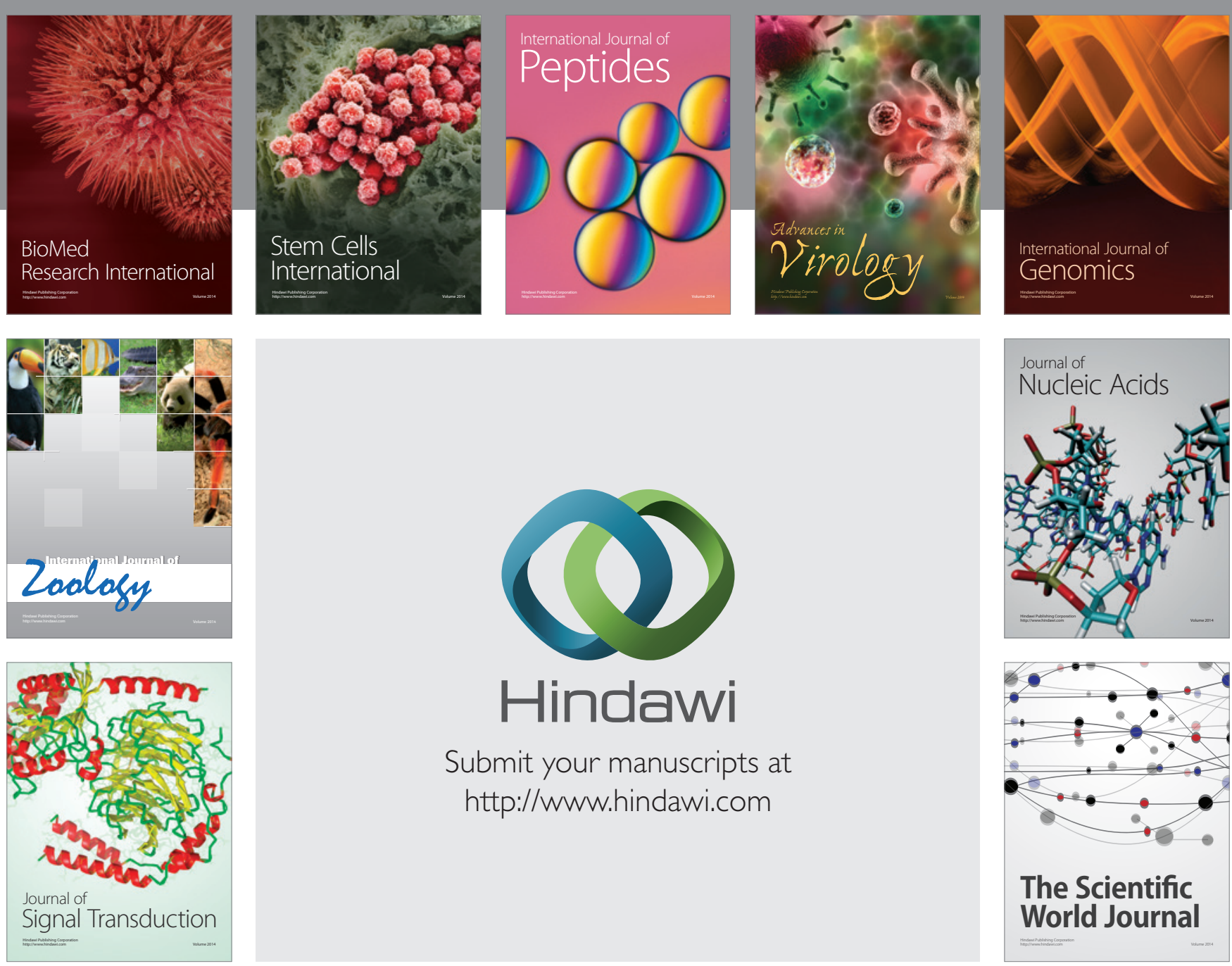

Submit your manuscripts at

http://www.hindawi.com
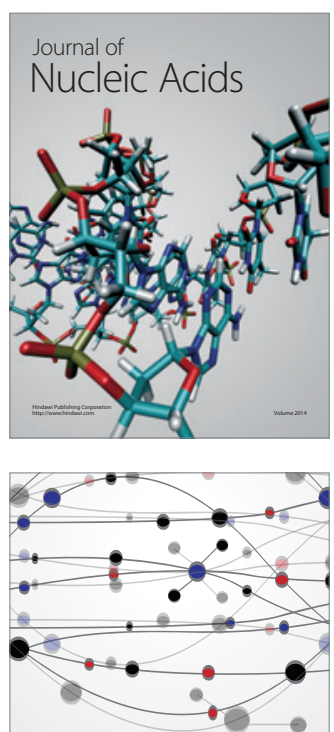

The Scientific World Journal
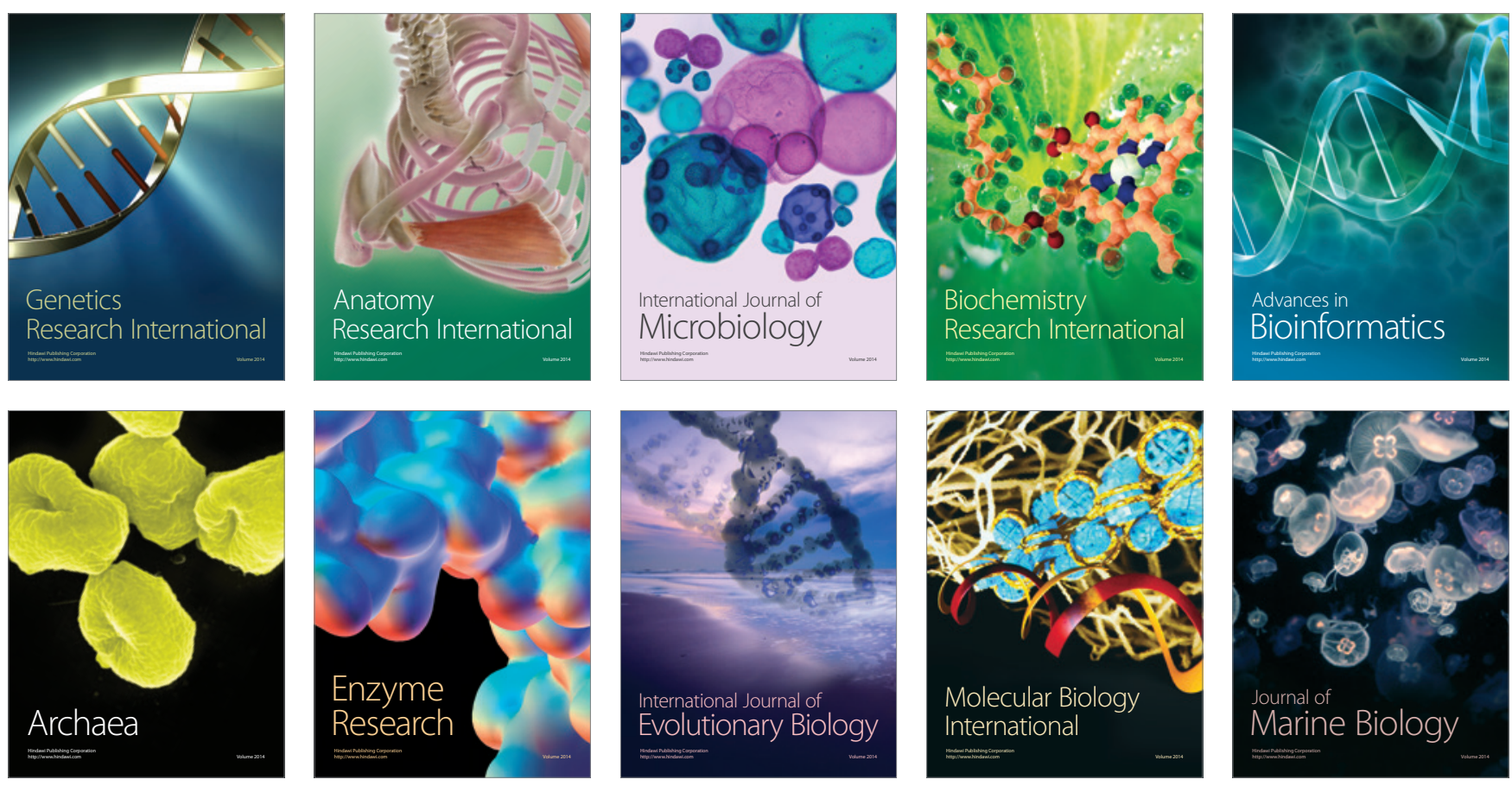